\title{
Preferred Techniques for Learning ESP Lexis by Generation Z
}

\author{
Lexis resists mastery
}

P. Medgyes

\begin{abstract}
Vocabulary has long been taught and learned through single words. The traditional learning involved making lists of words with their translations into learner native language. Although words are the key blocks of language, they do not occur individually. To produce coherent texts, words are combined and integrated into various situations. Language practitioners, who are unaware of recent linguistic research, usually use commercial textbooks that rely on grammar syllabus. In 1993, M. Lewis introduced a lexical approach which claims that language consists of meaningful word combinations known as chunks. Corpus studies confirmed that chunks dominate all language structures. It is acknowledged that acquisition of lexis is a very complex and demanding process. Learners of each generation use different ways of learning. Recognition and recall are two key concepts that demonstrate how learners can cope with receptive and productive skills. Recognition implies understanding lexis while reading or listening, and recall refers to learners' ability to remember and use it in speaking or writing. This article aims at investigating how students of Klaipeda University, who represent Generation Z (2000-present), prefer to learn English for Specific Purposes (ESP) lexis, which is one of key difficulties they encounter in learning English. The data are obtained from the two surveys that have been administered to the respondents. The analysis of the responses reveals that Generation Z prefers traditional ways of mastering lexis.
\end{abstract}

\section{Keywords:}

preferences in learning, ESP lexis, Generation Z, communicative approach, receptive knowledge 


\section{LITERATURE BACKGROUND}

A study of vocabulary has been an important area in language teaching and learning (Read, 2010). It is essential to note that there is a distinction between vocabulary, which is thought to be constituted of single items, and lexis, which includes word combinations. Lexical approach claims that language consists of meaningful chunks that, when combined, produce coherent texts (Rhalmi, 2009). In 1993, Michael Lewis published his famous book that presented taxonomy of lexical items. It was followed by description of its implementation (Lewis, 1997). However, many years after the publication, ELT remains resistant to change (Selivan, 2013). Corpus studies have confirmed that chunks dominate everyday English structures, and the central role of lexis has been recognized. Nevertheless, current textbooks rely on traditional grammar syllabus and the majority of language teachers are unaware of academic research into contemporary teaching practice. In this article, vocabulary and lexis will be used interchangeably.

There have been a number of publications in lexis research area. Overviews of research on second language acquisition in the 20th century were published by B. Harley (1995), J. Coady and T. Huckin (1997), and N. Schmitt and M. McCarthy (1997).

Acquisition of vocabulary is a demanding process. The traditional approach to vocabulary learning involved making lists of L2 words together with their L1 translations. Linguists sometimes claim that no word can be exactly translated into another language (Cook, 1996). The point is not just learning L2 words, but also remembering them. The remembering depends on how deeply learners process words. Although the words are the key blocks of language, they do not occur individually. Learners need to be aware of word families and their usage. Words are integrated into various texts and social situations. Communicative approach to language learning demands learners not only to develop language knowledge (Bachman and Palmer, 1996), but also strategic competence to deal with it (Read, 2000).

P. Meara (1994) investigated L2 vocabulary acquisition by university students, who had no prior knowledge of professional language: their learning takes a short time and involves a limited number of terms.

The teaching of vocabulary in ESP follows similar general principles to General English (Dudly-Evans and St John, 2000): it is important to distinguish between vocabulary needed for comprehension and needed for production. For production purposes, storage and retrieval are significant. 
T. Woodward (2008) pinpointed four important elements of learning new language: exposure, noticing, remembering or mental storage, and usage. Much of the noticing may be at the unconscious level, but most of the stages are necessary for new language to be learned.

Acquisition, storage, recognition, recall, and retrieval are major learner's concern (Rivers, 1992). Human memory is structured, and what learners store depends on attention and motivation. Moreover, recognition and recall are different processes: people can recognize much more than they can retrieve.

Renewed attention was given to vocabulary problems by the publications of special issues in 2015 and 2017 by Language Teaching Research Journal. Editorials of these issues summarize articles that deal with ways of learning vocabulary. According to the editorial review by A. Coxhead (2015), vocabulary research and pedagogy is the focus of the special issue. It includes the following information: - B. Laufer's comments on four studies from a special group on vocabulary in the Japanese Association of Language Teachers; - N. Schmitt's contribution on the list of the 150 most common phrasal verbs of English; - four articles by different authors on issues of acquisition, which all take different approaches. Also many vocabulary researchers turned their attention to multi-word units; the theme of testing and assessment is exemplified by P. Nation's \& co-authors' article on design and validation of a Listening Vocabulary Levels Test. This test has five frequency levels and includes a selection of items from Academic Word List. It should be noted that each of these articles provides recommendations for teaching and learning, and suggestions for further research.

Contribution of Paul Nation, who is a leading researcher in language teaching methodology and vocabulary acquisition, is well acknowledged. The lifelong research findings into various aspects of lexis teaching have been summarized in his monograph (2013) that is often referred to by today's linguists. According to P. Nation's earlier research (2006), receptive knowledge of 8,000-9,000 word families is needed to understand authentic written English, and knowledge of 6,000-7,000 families to be able to understand spoken English. Tests of receptive vocabulary size (Laufer, 2017) show that L2 learners know between 2,000-4,000 word families. It means that researchers and teachers must find effective methods to help learners acquire the lexis they need. Some proponents believe that the best way to learn vocabulary is by reading a lot of materials. Other researchers claim that during extensive reading learners must encounter new words at least 12 times. B. Laufer introduced three components of learner involvement: need, search and evaluation: the higher the involvement, the better the retention of the vocabulary. 
The latest idea proposed by B. Laufer (2017) is the three I's of vocabulary acquisition: Input, Instruction and Involvement.

The most recent editorial publication in Language Teaching Research Journal concerns searching for effective methods of vocabulary learning. This issue contains the debate between the advocates of 'vocabulary-through-input' and the proponents of 'word-focused instruction'. There are five articles by various authors that describe empirical studies of methods of vocabulary learning. Moreover, two other articles investigate the effect of different output tasks on learning new words. However, the value of output must be appreciated by languages practitioners. The outcome of the comparison of various data has been summarized by Laufer in two Tables, which demonstrate success rate (in percentage). The highest success of $94 \%$ was achieved by Reading + Instruction activities, Composition Writing (80\%), Summarizing, Predicting, Question \& Answer Activities (all about 70\%). On the basis of the reviewed single studies, however, a question whether teachers can extrapolate how many words students will learn in a year remains unanswered.

According to Dubiner (2017), one way to encourage vocabulary development amongst language learners is keeping a vocabulary notebook. The participants in her research were 13 third-year students in Israel. Results indicate positive outcomes in vocabulary acquisition and retention. However, it might be interpreted as a particular case in a certain country.

Language practitioners are interested in acquisition of ESP lexis by students who study various subjects at tertiary level. Students' self-grading of ESP vocabulary and their performance in written ESP vocabulary tests were compared by Janulevicienè and Kavaliauskienè (2007). The respondents were full-time university students, who studied ESP for 3 semesters, which amounted to 192 hours of instruction. Vocabulary was graded as follows: $20 \%$ excellent and very good, $50 \%$ good, 20\% average, and 10\% satisfactory. Students' performance in written ESP vocabulary tests was quite different: $15 \%$ excellent and very good, $10 \%$ good, $20 \%$ average, $15 \%$ satisfactory, $25 \%$ weak, and $15 \%$ poor. In other words, $40 \%$ of learners overestimated their knowledge of vocabulary. The key cause of linguistic deficit might be students' inability to internalize vocabulary knowledge, i.e. to transfer knowledge to its usage.

L.C. Lancaster and D. Stillman (2002) identified four distinct generations of learners since the 1950s; Baby Boomer Generation (1946-1964), Generation X (1965-1980), Generation Y (1981-1999), and Generation Z (2000-present). Generation Y, born in the mid-1980s or later, is also known as the Millennials, or the Internet generation. P. Reilly (2012) was the first who described how to understand and teach Generation Y. This generation grew up with IT, prefers to communicate 
through text messaging rather than face-to-face (Schroer, 2012). Investigation of Generation Y difficulties in ESP was conducted by G. Kavaliauskienè (2012). The participants in her research were the 1st year students who studied English for Psychology and for Social Work. The findings demonstrated that the main difficulty that learners faced was writing definitions of ESP vocabulary.

Language-related difficulties were reported by S. Evans and B. Morrison (2011), who questioned a group of 28 undergraduates. Understanding and using professional lexis was the key source of learners' difficulties. Earlier Sanders and Morrison (2007) questioned 277 first year students and discovered that Gen Y prefers IT to a textbook, because they read less than previous generations. Limited reading hinders learning of vocabulary.

A small-scale exploratory research involving 21 students and 100 minutes of class a week was conducted on intentional learning of vocabulary. In spite of the large enough gain on the mastery of new words, the teaching of new lexis should put emphasis on the intensity of practice (Djiwandono, 2013).

The brief review of vocabulary learning tips can be found online (Sheppard, 2017). The key tips include reading, practicing, using dictionary, using vocabulary lists and mnemonics, making associations and connections as well as taking vocabulary tests and getting excited about words.

According to P. Trinder (2017), opportunities for the incidental and informal practice of English have increased due to the availability of new technologies. The term of 'incidental and informal learning' refers to learner-controlled learning, i.e. not linked to any course or institution, and it takes outside the classroom. The respondents in P. Trinder's study (2017) were 175 Austrian university students. Results show how young adults practice informal learning. The author examined the frequencies of regularly used Information Technology (IT) and its usefulness. It appeared that online dictionaries were used by $94 \%$ of learners and $74 \%$ think them very useful; 73\% watched TV/video clips and 67\% found them useful; 58\% were involved in social networking (Facebook) and 23\% benefited from it; online news sites/journals were frequented by $45 \%$ of learners with $51 \%$ benefiting from them; chats (Skype, Messenger) were less popular, just 36\% used media and only $23 \%$ believed it useful. There are a number of other technologies included in this research, but their usefulness is not very significant. Summing up, getting insights into how students use technology outside classrooms might help teachers to integrate motivating technologies that promote informal learning of all language skills, not just lexis.

Similarly as Generation Y (1981-1999), Generation Z (2000-present) is identified as confident and technologically advanced. Some researchers refer to both 
Generations as digital natives who have never known life without computers and the Internet, i.e. IT is an integral part of their lives. Both generations read and write less: the "screenagers" are more visual than textual. Since they are keen on learning online with listening and speaking being their priorities, it helps teachers to plan meaningful class activities and keep learners motivated.

This article aims at investigating students' learning difficulties in English for Specific Purposes (ESP) and their preferred techniques for lexis acquisition by means of online resources.

\section{RESPONDENTS}

The respondents are the students of Klaipeda University. The students are the native speakers of Lithuanian. They studied General English at secondary schools. The design of the English courses at university reflects the students' future needs in professional language. The courses are adjusted to the requirements for a Bachelor degree. The level of students' proficiency is B2 in accordance with the Common European Framework of Reference for Languages.

\section{RESEARCH METHODOLOGY}

The data have been obtained from the two surveys completed by 50 respondents. The surveys are shown in the Appendix. Survey 1 contains a list of difficulties that students might have in learning English at university level. This survey was designed by P. Medgyes (1994), who studied the problem areas of non-native English speakers. Survey 2 was designed in accordance with the accepted standards (Dornyei, 2003) and contains statements on students' preferred ways of learning lexis. The students responded on a 5-point Likert's scale ranging from 1 'strongly disagree' to 5 'strongly agree'. It is important to emphasize that common ways of learning vocabulary by using cue-cards (flash cards) and mnemonic techniques have not been included in Survey 2. This idea is supported by the attitude expressed by the experts who claim that these methods are beneficial to young learners and not to learners at university level (Vliet, 2013). 


\section{RESULTS AND DISCUSSION}

This section reports the findings of both surveys. The survey 1 (in Appendix) refers to the respondents' evaluation of learning difficulties. The obtained findings are summarized in Table below.

Table. Frequency of language difficulties (in percentage).

\begin{tabular}{|c|c|c|}
\hline Difficulty & $\begin{array}{c}\text { Frequency of difficulties } \\
\text { by current respondents, \% } \\
\text { Number of respondents N=50 }\end{array}$ & $\begin{array}{c}\text { Frequency of difficulties by } \\
\text { non-native speakers, \% } \\
\text { (after P.Medgyes, 1994). } \\
\text { Number of respondents N=198 }\end{array}$ \\
\hline vocabulary & 36 & 42 \\
\hline listening & 14 & 20 \\
\hline speaking & 6 & 28 \\
\hline writing & 64 & 2 \\
\hline tenses & 56 & 5 \\
\hline phrasal verbs & 62 & 7 \\
\hline prepositions & 34 & 9 \\
\hline idioms & 22 & 16 \\
\hline word order & 14 & 3 \\
\hline
\end{tabular}

The frequency of language difficulties that our students (who represent Generation Z) indicated is shown (in percentage) in the 2nd column of Table. For comparison, P. Medgyes's data are presented in the 3rd column. Medgyes's data refer to the international survey that was designed and administered in 1990-1992 to 216 respondents from 10 countries. Out of the 216 respondents only 18 (8.3\%) claimed to be native speakers of English, and the remaining 198 (91.7\%) spoke one of 17 languages as their mother tongue. Thus, this sample overwhelmingly consisted of non-native English speakers who were NOT students of Generation $\mathrm{Y}$ - they were English language teachers of various ages. The aim of presenting Medgyes's data in this article is to demonstrate the trend, i.e. the general tendency of language learning difficulties that are encountered by non-native learners. It should be mentioned that, according to P. Medgyes, native and non-native English speakers differ in terms of their language proficiency and to achieve native-like proficiency is wishful thinking. Coming back to this Table, it is seen that learning vocabulary is hard to $36 \%$ of our respondents, and the trend is similar to the reference result. The frequency of difficulties would be higher if some other items in Table, such as prepositions, phrasal verbs and idioms, were added, i.e. not presented 


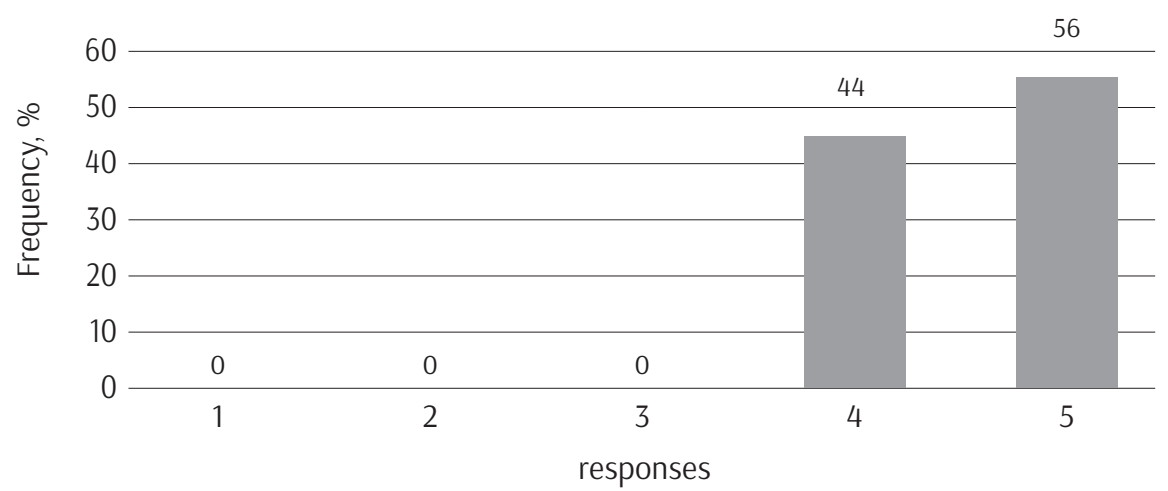

\section{Chart 1. Lerning lexis from contexts}

Numbers 1 and 2 on $\mathrm{X}$ axis of Chart 1 refer to the responses strongly disagree and disagree, number 3 refers to the not sure response, numbers 4 and 5 refer to agree and strongly agree responses.

separately. According to P. Medgyes (1994), vocabulary resists mastery due to the fact that in any language as well as English there are a lot of lexical items, which are used in multiple contexts. Moreover, P. Medgyes emphasizes that non-native English learners feel hopelessly insecure about the usage of vocabulary because there cannot be a dictionary which will guide a learner to the appropriate use of lexis. Tenses (56\%) and writing (64\%), which are also relevant to vocabulary knowledge, constitute other difficulties to the Lithuanian students. It should also be noted that percentage of some difficulties in P. Medgyes's data significantly differs from our results, which clearly indicates the diversity in language knowledge and proficiency between students and languaage teachers.

Survey 2 has been designed to find out learners' priorities in the ways of learning ESP lexis. Students' responses to the statements are displayed in the following Charts. It is important to emphasize that learning activities of our students are supported by the means of IT.

Chart 1 shows the frequency of responses to the 1st statement of Survey 2. It can be seen that all respondents (100\%) claim they learn vocabulary from online reading and listening contexts. Their responses are: 44\% refer to agree and 56\% - to strongly agree opinion.

Chart 2 refers to the intricacies of learning vocabulary by writing definitions of unknown words. Overwhelmingly, 94\% of students reject this idea and just a few students agree with it: $70 \%$ of respondents strongly disagree, and $24 \%$ of respondents disagree, while $4 \%$ of respondents are not sure, and $2 \%$ agree. The obvious dislike of our learners to writing definitions of unknown ESP vocabu- 


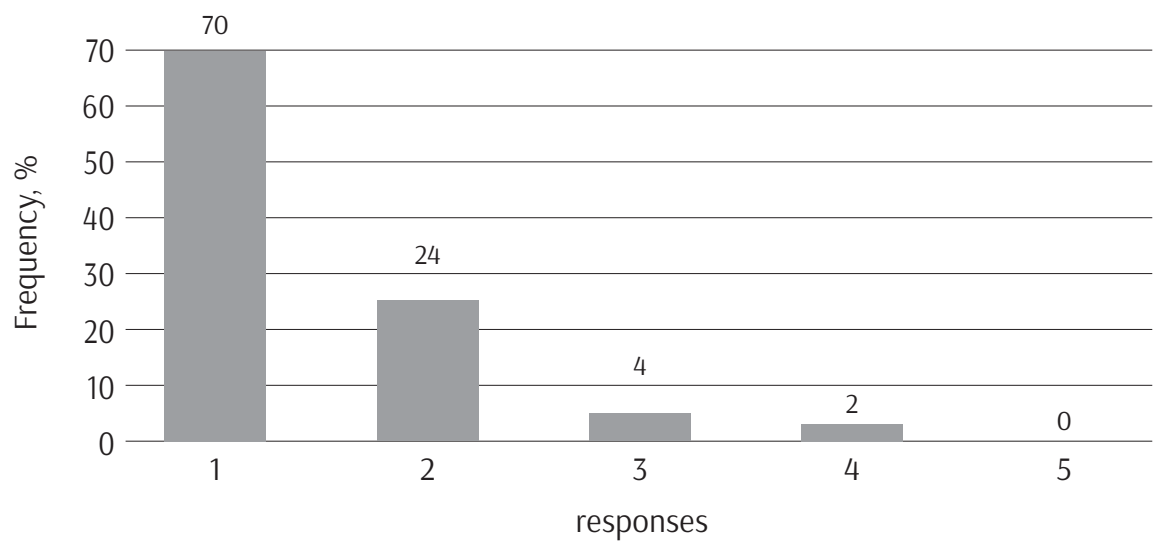

\section{Chart 2. Writing definitions}

Chart 2 Frequency of responses to the statement No 2 of Survey 2. Numbers 1 and 2 on $X$ axis refer to the responses strongly disagree and disagree, number 3 refers to the not sure response, numbers 4 and 5 refer to agree and strongly agree responses.

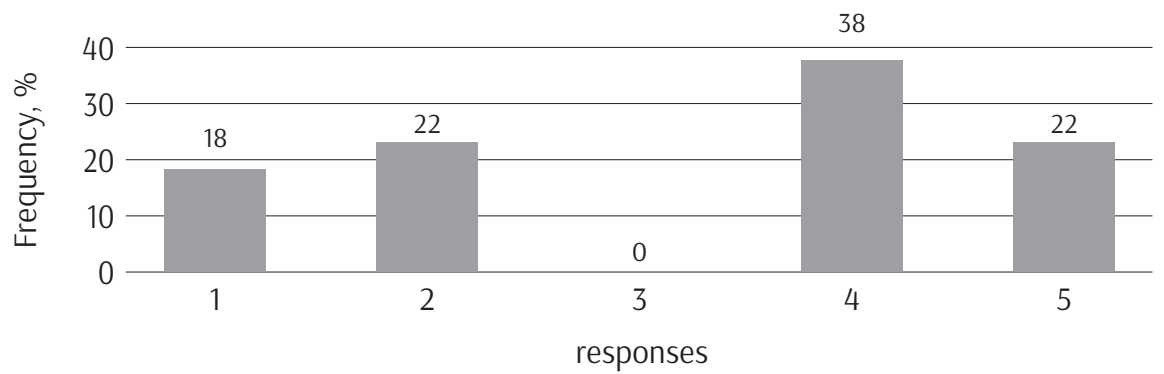

\section{Chart 3. Writing translation lists}

Chart 3 Frequency of responses to the statement No 3 of Survey 2. Numbers 1 and 2 on X axis refer to the responses strongly disagree and disagree, number 3 refers to the not sure response, numbers 4 and 5 refer to agree and strongly agree responses.

lary items correlates with the previous findings that have been mentioned above: writing definitions was a key difficulty for university students (Kavaliauskienė, 2012).

Chart 3 reveals data on writing electronic lists of vocabulary translations either in respondents' smart phones or laptops. $60 \%$ of the respondents contend they apply this way of learning - 38\% of them agree, $22 \%$ - strongly agree, while $40 \%$ of the respondents refrain from this activity $-18 \%$ strongly disagree and $22 \%$ disagree. 


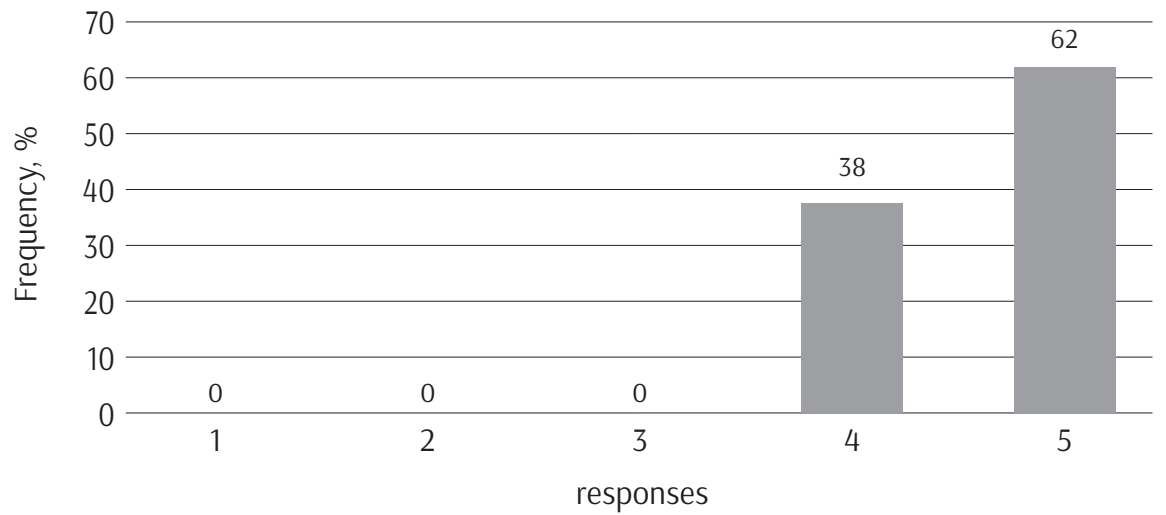

\section{Chart 4. Using a dictionary}

Chart 4 Frequency of responses to the statement No 4 of Survey 2. Numbers 1 and 2 on X axis refer to the responses strongly disagree and disagree, number 3 refers to the not sure response, numbers 4 and 5 refer to agree and strongly agree responses.

Chart 4 shows students' attitudes to using either online or paper dictionary for looking up the meanings of unknown vocabulary items. It can be seen that respondents are overwhelmingly in the favour of looking up the meanings of the new lexis in a dictionary: 38\% agree and 62\% strongly agree with the usefulness of this activity.

There is a certain discrepancy between the results displayed in Chart 3 and Chart 4. On the one hand, according to Chart 4, students use dictionaries to translate unknown words, but, on the other hand, according to Chart 3, 40\% of learners do not write translation lists from English to their native language. It seems we have to assume that $40 \%$ of respondents do not keep any notes on professional lexis they need to learn, which might be relevant to respondents with well developed musical intelligence but not to visial learners (Gardner, 2006).

Chart 5 displays the frequency of responses to the usage of new vocabulary in English classrooms.

It turned out that 54\% of the learners disagreed to practicing and using new lexis in English classrooms (30\% strongly disagree and 24\% disagree), while 46\% of the students (34\% agree and 12\% strongly agree) supported this method of consolidating lexis. This result correlates with the findings that were reported by S. Evans and B. Morrison (2011) who found that the key source of learners' difficulties was using professional lexis.

Summing up the frequency of responses to the ways of consolidating new lexis, it would not be an exaggeration to suggest that in order to cope with the 


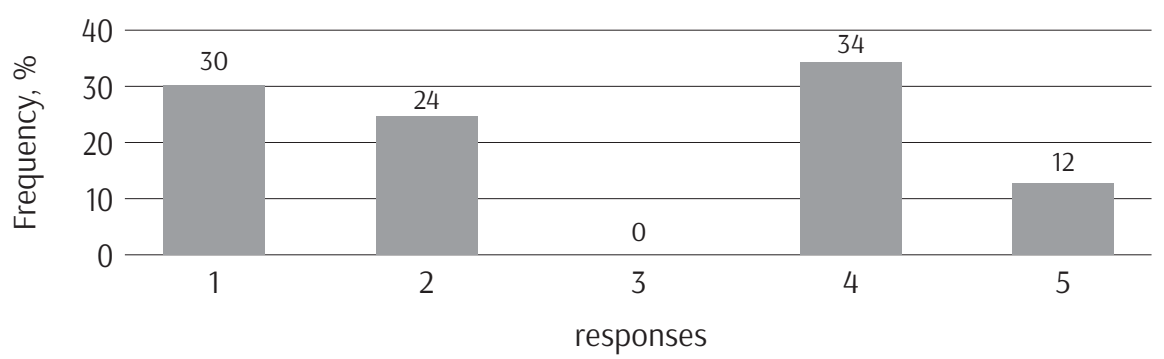

\section{Chart 5. Using lexis in class}

Chart 5 Frequency of responses to the statement No 5 of Survey 2. Numbers 1 and 2 on X axis refer to the responses strongly disagree and disagree, number 3 refers to the not sure response, numbers 4 and 5 refer to agree and strongly agree responses.

issue of learning professional vocabulary students prefer common techniques that have been familiar to them, i.e. to learn it from either online reading or listening contexts and to look up the meanings of unknown items in a dictionary.

A revelation of prejudiced attitude to writing definitions might be due to a handicap in terms of command of English, i.e. to avoid vague concepts and find out accurate meanings of unknown vocabulary items.

Having identified students' language weaknesses and the preferred techniques of learning new lexis, we seem to be unable to claim that Generation Z essentially differs from Generation Y (Reilly, 2012) in their studying habits.

Summing up, it is worth mentioning that vocabulary learning is often out of teacher's hand: in spite of lexis being easily "teachable", it is not easily "learnable" (Medgyes, 1994). The possible reasons might be caused by students’ aptitude for learning a language or other individual differences such as a personality or motivation.

As it has been mentioned before (Trinder, 2017), new technologies increase the opportunities for incidental and informal learning outside language classes. Therefore, the implications for future research might be for teachers to get insights how students can use technologies for improving their English outside the classrooms.

\section{CONCLUSIONS}

Regardless of a rather limited number of the respondents, who represent Generation $\mathrm{Z}$ in this research, some conclusions could be drawn. First, lexis is the most 
common problem area in learning ESP. Second, students prefer to learn lexis from online listening and reading contexts (Chart 1). Third, similarly as Generation $\mathrm{Y}$, the respondents of Generation $\mathrm{Z}$ do not favor writing definitions of unknown words (Chart 2). Fourth, the learners are not unanimous in the attitude to writing translation lists (Chart 3), and, although the mother tongue is known as a teaching device for understanding vocabulary, some students make efforts to translate lexis items into their native language using either online or paper dictionary (Chart 4). Fifth, according to Chart 5, half of the respondents do not enjoy practicing professional lexis in the classroom. It implies that to cater for the needs of learners, teachers need to develop vocabulary building techniques by selecting appropriate class activities to consolidate new lexis in English classrooms. And finally, here is some information for thought: recent research into differences between Generation Z and Millennials (or Generation Y) indicates that 1) Generation Z processes information faster than other generations, 2) prefers multitasking to working on a single task, 3) knows the true value of independence, 4) is more global in their thinking and interactions, 5) uses social media less often, and 6) finds it hard to do without IT (Beall, 2017).

\section{References}

Bachman, L.F. (2005). Statistical Analyses for Language Assessment. Cambridge: Cambridge University Press.

Bachman, L.F., \& A.S. Palmer. (1996). Language Testing in Practice. Oxford: Oxford University Press.

Beall, G. (2017). 8 Key Differences between Gen Z and Millennials. Retrieved from: https:// www.huffingtonpost.com/george-beall/8-key-differences-between_b_12814200. html?guccounter=1 (accessed: March 21, 2018).

Coady, J. and T. Huckin (Eds.). (1997). Second Language Vocabulary Acquisition. Cambridge: Cambridge University Press.

Coxhead, A. (2015). Vocabulary Research and Pedagogy: Introduction to this Special Issue, Language Teaching Research, 19 (6), pp. 641-644.

Cook, V. (1996). Second Language Learning and Language Teaching. Arnold: London-New York-Sydney-Auckland.

Djiwandono, P.I. (2013). A Blended Learning Approach to Enhance College Students’ Vocabulary Learning, Electronic Journal of Foreign Language Teaching, 10 (2), pp. 210-220.

Dornyei, Z. (2003). Questionnaires in Second Language Research. Lawrence Erlbaum Associates, Inc.

Dubiner, D. (2017). Using Vocabulary Notebooks for Vocabulary Acquisition and Teaching, ELT Journal, 71(4), pp. 456-466.

Dudly-Evans, T., \& St John, M.J. (2000). Developments in English for Specific Purposes. A Multi-disciplinary Approach. Cambridge: Cambridge University Press. 
Evans, S., \& Morrison B. (2011). The First Term at University: Implications for EAP, ELT Journal, 65 (4), pp. 387-39.

Gardner, H. (2006), Multiple Intelligences: New Horizons in Theory and Practice. New York: Basic Books.

Harley, B. (1995). Introduction: the Lexicon in Second Language Learning. In: B. Harley (Ed.) Lexical Issues in Language Learning (pp. 1-28). Amsterdam: John Benjamins.

Janulevicienė, V., \& Kavaliauskienė, G. (2007). Self-Assessment of Vocabulary and Relevant Language Skills for Evaluation Purposes, Santalka, 15 (4), pp. 10-15.

Kavaliauskienè, G. (2012). Challenges in ESP: Teaching Millennials, English for Specific Purposes World, 12 (36). Retrieved from: http://www.esp-world.info (accessed: March 21, 2018).

Lancaster, L.C., \& Stillman, D. (2002). When Generations Collide: Who They Are, Why They Clash, How to Solve the Generational Puzzle at Work. New York: Harper Collins.

Laufer, B. (2017a). From Word Parts to Full Texts: Searching for Effective Methods of Vocabulary Learning, Language Teaching Research, 21 (1), pp. 5-11.

Laufer, B. (2017b). The Three 'I’s of Second Language Vocabulary Learning: Input, Instruction and Involvement. In: E. Hinkel (Ed.), Handbook of Research in Second Language Teaching and Learning (pp. 15-27). Bristol: Multilingual Matters.

Lewis, M. (1993). The Lexical Approach: The State of ELT and the Way Forward. Hove, England: Language Teaching Publications.

Lewis, M. (1997). Implementing the Lexical Approach: Putting Theory into Practice. Hove, England: Language Teaching Publications.

Meara, P. (1994). Second Language Acquisition: Lexis. In: R.E. Asher (Ed.), The Encyclopedia of Language and Linguistics (pp. 3726-3728), vol. 7.

Medgyes, P. (1994). The Non-Native Teacher. Macmillan Publishers Ltd.

Nation, P. (2006). How Large a Vocabulary is Needed for Reading and Listening?, The Canadian Modern Language Review, 63, pp. 59-82.

Nation, P. (2013). Learning Vocabulary in Another Language. 2nd edition. Cambridge: Cambridge University Press.

Read, J. (2010). Assessing Vocabulary. Cambridge: Cambridge University Press.

Reilly, P. (2012). Understanding and Teaching Generation Y, English Teaching Forum, 5 (1), pp. 2-12. Retrieved from: https://americanenglish.state.gov/files/ae/resource_files/50_1_ 3_reilly.pdf (accessed: March 21, 2018).

Rivers, W.M. (1992). Communicating Naturally in a Second Language. Theory and Practice in Language Teaching. Cambridge: Cambridge University Press.

Rhalmi, M. (2009). The Lexical Approach. http://www.myenglishpages.com/blog/lexicalapproach/.

Schroer, W. (2012). Generations X, Y, Z and the Others. http://www.socialmarketing.org/newsletter/features/generation3.htm.

Sanders, S., \& Morrison, B. (2007). What is the Net Generation? The Challenge for Future Medical Education, Medical Teacher, 29 (2/3), pp. 85-88.

Selivan, L. Why Has the Lexical Approach Been so Long in Coming? Retrieved from: https:// www.theguardian.com/education/2013/mar/26/lexical-approach-revolution 
Sheppard, B. Jr. (2017). The Ten Best Vocabulary Learning Tips. Retrieved from: http://www. sheppardsoftware.com/vocabulary tips.htm (accessed: March 21, 2018).

Schmitt, N., \& McCarthy, M. (1997). Vocabulary: Description, Acquisition and Pedagogy. pp. 84-102. Cambridge: Cambridge University Press.

Trinder, R. (2017). Informal and Deliberate Learning with New Technologies, ELT Journal, 71 (4), pp. 401-412.

Woodward, T. (2008). Planning Lessons and Courses. In: P. Ur (Ed.), Cambridge Handbooks for Language Teachers (p. 91). Cambridge: Cambridge University Press.

Vliet van, N. (2013). 38 Language-Learning Experts Reveal Their Favorite Methods for Learning Vocabulary. Retrieved from: https://www.smartlanguagelearner.com/experts-revealmethod-learning-vocabulary/ (accessed: March 21, 2018).

\section{Appendix}

Survey 1. Frequency of language difficulties (after P. Medgyes, 1994)

\begin{tabular}{|c|c|}
\hline Difficulty & Frequency, \% \\
\hline vocabulary & \\
\hline listening & \\
\hline speaking & \\
\hline writing & \\
\hline reading & \\
\hline phrasal verbs & \\
\hline prepositions & \\
\hline idioms & \\
\hline word order & \\
\hline tenses & \\
\hline
\end{tabular}

\section{Survey 2. Preferred learning techniques of ESP vocabulary}

No 1. I learn vocabulary from online reading or listening contexts. 1 - strongly disagree, 2 - disagree, 3 - not sure, 4 - agree, 5 - strongly agree.

No 2. I learn words by writing definitions of vocabulary items. 1 - strongly disagree, 2 - disagree, 3 - not sure, 4 - agree, 5 - strongly agree.

No 3. I write vocabulary translation e-lists (English vs. Lithuanian). 1 - strongly disagree, 2 - disagree, 3 - not sure, 4 - agree, 5 - strongly agree.

No 4. I look up the meanings of unknown words in either online or paper dictionary. 1 - strongly disagree, 2 - disagree, 3 - not sure, 4 - agree, 5 - strongly agree.

No 5. I keep practicing and using new vocabulary in English classes. 1 - strongly disagree, 2 - disagree, 3 - not sure, 4 - agree, 5 - strongly agree. 